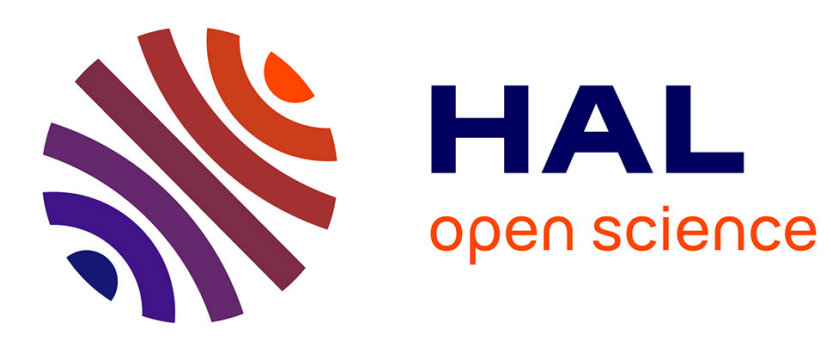

\title{
A Jacobson's beetle from Cretaceous Charentese amber (Coleoptera: Jacobsoniidae)
}

Erik Tihelka, David Peris, Chenyang Cai, Vincent Perrichot

\section{To cite this version:}

Erik Tihelka, David Peris, Chenyang Cai, Vincent Perrichot. A Jacobson's beetle from Cretaceous Charentese amber (Coleoptera: Jacobsoniidae). Geodiversitas, 2022, 44 (3), pp.47-56. 10.5252/geodiversitas2022v44a3 . insu-03540558

\section{HAL Id: insu-03540558 \\ https://hal-insu.archives-ouvertes.fr/insu-03540558}

Submitted on 24 Jan 2022

HAL is a multi-disciplinary open access archive for the deposit and dissemination of scientific research documents, whether they are published or not. The documents may come from teaching and research institutions in France or abroad, or from public or private research centers.
L'archive ouverte pluridisciplinaire HAL, est destinée au dépôt et à la diffusion de documents scientifiques de niveau recherche, publiés ou non, émanant des établissements d'enseignement et de recherche français ou étrangers, des laboratoires publics ou privés. 


\section{geodiversitas $2022 \cdot 44 \cdot 3$}

\section{A Jacobson's beetle from Cretaceous Charentese amber (Coleoptera: Jacobsoniidae)}

Erik TIHELKA, David PERIS, Chenyang CAI \& Vincent PERRICHOT

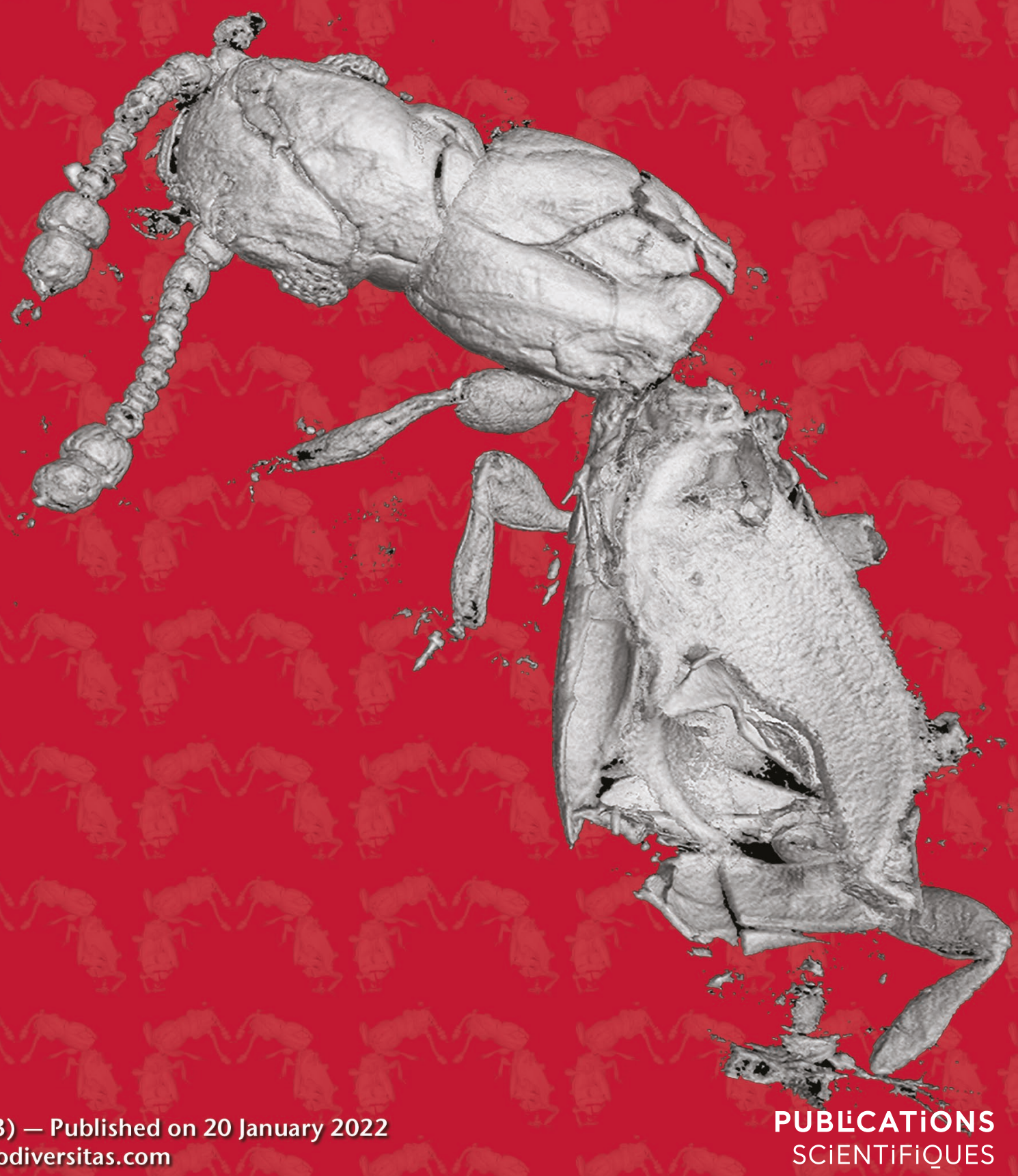


Directeur de la publication / Publication director: Bruno David, Président du Muséum national d'Histoire naturelle

RÉdACTEUR EN CHEF / EDITOR-IN-CHIEF: Didier Merle

ASSISTANT DE RÉDACTION / ASSISTANT EDITOR: Emmanuel Côtez (geodiv@mnhn.fr)

Mise en PAge / PAGE LAYOUt: Chris Le Coquet-Le Roux

COMITÉ SCIENTIFIQUE / SCIENTIFIC BOARD:

Christine Argot (Muséum national d'Histoire naturelle, Paris)

Beatrix Azanza (Museo Nacional de Ciencias Naturales, Madrid)

Raymond L. Bernor (Howard University, Washington DC)

Alain Blieck (chercheur CNRS retraité, Haubourdin)

Henning Blom (Uppsala University)

Jean Broutin (Sorbonne Université, Paris, retraité)

Gaël Clément (Muséum national d'Histoire naturelle, Paris)

Ted Daeschler (Academy of Natural Sciences, Philadelphie)

Bruno David (Muséum national d'Histoire naturelle, Paris)

Gregory D. Edgecombe (The Natural History Museum, Londres)

Ursula Göhlich (Natural History Museum Vienna)

Jin Meng (American Museum of Natural History, New York)

Brigitte Meyer-Berthaud (CIRAD, Montpellier)

Zhu Min (Chinese Academy of Sciences, Pékin)

Isabelle Rouget (Muséum national d'Histoire naturelle, Paris)

Sevket Sen (Muséum national d'Histoire naturelle, Paris, retraité)

Stanislav Štamberg (Museum of Eastern Bohemia, Hradec Králové)

Paul Taylor (The Natural History Museum, Londres, retraité)

COUVERTURE / COVER:

Réalisée à partir des Figures de l'article/Made from the Figures of the article.

Geodiversitas est indexé dans / Geodiversitas is indexed in:

- Science Citation Index Expanded (SciSearch $\left.{ }^{\circledR}\right)$

- ISI Alerting Services ${ }^{\circledR}$

- Current Contents ${ }^{\circledR} /$ Physical, Chemical, and Earth Sciences ${ }^{\circledR}$

- Scopus ${ }^{\circledR}$

Geodiversitas est distribué en version électronique par / Geodiversitas is distributed electronically by:

- BioOne ${ }^{\circledR}$ (http://www.bioone.org)

Les articles ainsi que les nouveautés nomenclaturales publiés dans Geodiversitas sont référencés par / Articles and nomenclatural novelties published in Geodiversitas are referenced by:

- ZooBank ${ }^{\circledR}$ (http://zoobank.org)

Geodiversitas est une revue en flux continu publiée par les Publications scientifiques du Muséum, Paris Geodiversitas is a fast track journal published by the Museum Science Press, Paris

Les Publications scientifiques du Muséum publient aussi / The Museum Science Press also publish: Adansonia, Zoosystema, Anthropozoologica, European Journal of Taxonomy, Naturae, Cryptogamie sous-sections Algologie, Bryologie, Mycologie, Comptes Rendus Palevol

Diffusion - Publications scientifiques Muséum national d'Histoire naturelle

CP $41-57$ rue Cuvier F-75231 Paris cedex 05 (France)

Tél.: 33 (0)1 40794805 / Fax: 33 (0)1 40793840

diff.pub@mnhn.fr / http://sciencepress.mnhn.fr

(C) Publications scientifiques du Muséum national d'Histoire naturelle, Paris, 2022

ISSN (imprimé / print): 1280-9659/ ISSN (électronique / electronic): 1638-9395 


\title{
A Jacobson's beetle from Cretaceous Charentese amber (Coleoptera: Jacobsoniidae)
}

Erik TIHELKA

School of Earth Sciences, University of Bristol Life Sciences Building, Tyndall Avenue, Bristol, BS8 1TQ (United Kingdom)

David PERIS

Section Paleontology, Institute of Geosciences, University of Bonn 53115 Bonn (Germany)

Chenyang CAI

State Key Laboratory of Palaeobiology and Stratigraphy Nanjing Institute of Geology and Palaeontology, and Center for Excellence in Life and Paleoenvironment, Chinese Academy of Sciences Nanjing 210008 (China) and School of Earth Sciences, University of Bristol Life Sciences Building, Tyndall Avenue, Bristol, BS8 1TQ (United Kingdom) cycai@nigpas.ac.cn (corresponding author)

Vincent PERRICHOT Univ. Rennes, CNRS, Géosciences Rennes UMR 6118, F-35000, Rennes (France) vincent.perrichot@univ-rennes1.fr (corresponding author)

Submitted on 25 April 2020 | accepted on 21 July 2020 | published on 20 January 2022

urn:Isid:zoobank.org:pub:FE34C416-DE4A-4881-9734-26DD3B3DEB53

Tihelka E., Peris D., Cai C. \& Perrichot V. 2022. - A Jacobson's beetle from Cretaceous Charentese amber (Coleoptera: Jacobsoniidae). Geodiversitas 44 (3): 47-56. https://doi.org/10.5252/geodiversitas2022v44a3. http://geodiversitas.com/44/3

\begin{abstract}
Jacobsoniidae is a species-poor family of minute polyphagan beetles distributed in tropical and subtropical regions. Both extant representatives of the family as well as fossils are rare. Here we describe a new fossil species, Derolathrus capdoliensis n. sp., from latest Albian-earliest Cenomanian Charentese amber from the Cadeuil deposit, Charente-Maritime department in south-western France. The new species is defined by several unusual characters, most notably the co-joined but not fully fused two apical antennomeres. Derolathrus capdoliensis n. sp. is approximately contemporaneous with Kachin amber (burmite), filling an important geographical gap in the Mesozoic distribution of the family. The widespread distribution of jacobsoniid beetles in the Cretaceous, encompassing the Tethyan and Austral realms, indicates a more widespread distribution of the family during this time than in the present day and suggests that the current biogeographical range of Jacobsoniidae may be a result of extinction in northern regions. The new species shows remarkable similarity to extant members of the genus and provides further evidence of prolonged morphological, and probably also ecological, stasis in Jacobsoniidae since at least the Cretaceous.
\end{abstract}

KEY WORDS Derolathrus, Mesozoic,

fossil,

Cadeuil 


\begin{abstract}
RÉSUMÉ
Un coléoptère de Jacobson dans l'ambre crétacé des Charentes (Coleoptera: Jacobsoniidae).

Les Jacobsoniidae sont une famille peu diversifiée de minuscules coléoptères polyphages présents dans les régions tropicales et subtropicales. Les représentants actuels de la famille ainsi que les fossiles sont rares. Nous décrivons ici une nouvelle espèce fossile, Derolathrus capdoliensis n. sp., provenant de l'ambre charentais de l'Albien supérieur ou Cénomanien inférieur du gisement de Cadeuil, dans le département de la Charente-Maritime, dans le sud-ouest de la France. La nouvelle espèce est définie par plusieurs caractères inhabituels, notamment ses deux antennomères apicaux co-joints mais pas complètement fusionnés. Derolathrus capdoliensis n. sp. est approximativement contemporain de l'ambre birman du Kachin (burmite), comblant ainsi une importante lacune géographique dans la distribution mésozoïque de la famille. La large distribution des coléoptères jacobsoniidés au Crétacé, englobant les provinces téthysienne et australe, indique une distribution plus étendue de la famille à cette période qu'à l'heure actuelle et suggère que l'aire biogéographique actuelle des Jacobsoniidae pourrait résulter d'une extinction dans les régions septentrionales. La nouvelle espèce montre une similarité remarquable avec les membres existants du genre et fournit des preuves supplémentaires d'une stase morphologique, et probablement aussi écologique, prolongée chez les Jacobsoniidae depuis au moins le Crétacé.

\author{
MOTS CLÊS \\ Derolathrus, \\ fossile, \\ Cadeuil, \\ espèce nouvelle
}

\section{INTRODUCTION}

Jacobson's beetles (Jacobsoniidae Heller, 1926) is a small family of polyphagan beetles with only 24 extant and three extinct described species (Háva \& Löbl 2005; Lawrence \& Leschen 2010; Peck 2010; Bi et al. 2015; Háva 2016; Cai et al. 2016, 2017; Yamamoto et al. 2017; Yin \& Bi 2018). Recent species are distributed in New Zealand, the Indo-Australian region, Sri Lanka, Florida, and tropical islands (Lawrence $\&$ Leschen 2010; Peck 2010). All species in this family are small to minute (0.65-2.5 mm long) and little is known about their biology (Lawrence \& Leschen 2010). Many jacobsoniids are found in leaf litter and rotten wood, but some were also collected from more specific microhabitats such as fungal fruiting bodies and bat guano (Lawrence \& Leschen 2010).

The placement of the family within Coleoptera is controversial. Crowson $(1959,1960)$ first proposed a relationship between Jacobsoniidae and the superfamily Staphylinoidea although it was provisionally placed in the superfamily Dermestoidea together with Derodontidae, Nosodendridae, and Dermestidae. Subsequently, different authors proposed different classifications and Jacobsoniidae was placed within Cucujiformia (Sen Gupta 1979), Bostrichiformia (Lawrence \& Newton 1995; Philips et al. 2002), and finally Derodontiformia (Lawrence \& Leschen 2010; Bouchard et al. 2011). The most recent morphological and molecular phylogenetic studies support a close affinity of the family with Staphylinoidea (Lawrence et al. 2011; McKenna et al. 2015b, 2019; Toussaint et al. 2017; Zhang et al. 2018), which resulted in removing Jacobsoniidae from Derodontiformia and the family was treated as taxon incertae sedis within Polyphaga (Lawrence 2016), then formally placed in Staphylinoidea (Cai et al. 2021). Indeed, an affinity with Staphylinoidea is supported by wing venation characters and the morphology of the maxillary galea of the larvae (Crowson 1959, 1960). A study testing the monophyly of Jacobsoniidae is, however, still lacking.
Jacobsoniidae includes three extant genera with three recently described fossil species. Derolathrus groehni Cai, Leschen \& Huang, 2016 was the first fossil species belonging to the family to be described from middle Eocene Baltic amber (Cai et al. 2016). Later, D. abyssus Yamamoto \& Parker, 2017 and Sarothrias cretaceus Cai, Ślipiński, Leschen, Yin, Zhuo \& Huang, 2017 were described from mid-Cretaceous Kachin (Burmese) amber (Yamamoto et al. 2017; Cai et al. 2017). These fossils indicate that two out of the three current genera, Derolathrus Sharp in Sharp \& Scott 1908 and Sarothrias Grouvelle, 1918, are perfect examples of bradytely ('arrested evolution' sensu Simpson 1944); a long morphological stasis is similarly described in many other beetle lineages recorded from Cretaceous ambers (Clarke \& Chatzimanolis 2009; Chatzimanolis et al. 2013; Peris \& Háva 2016, Yamamoto et al. 2017; Cai et al. 2019). Derolathrus capdoliensis n. sp. is described herein as the oldest jacobsoniid species, pushing the definitive record of the family back some millions of years and, as with the rest of the fossil species, provides a new example of bradytely.

\section{MATERIAL AND METHODS}

\section{GEOLOGICAL SETTING}

The department of Charente-Maritime in south-western France has several Albian-Cenomanian amber deposits (Perrichot et al. 2010). The specimen studied herein was found in the Cadeuil deposit, a quarry near the town of Sainte-Gemme, located about ten kilometers from the Seudre estuary (Fig. 1; Perrichot et al. 2010). The alternating sand and clay beds where the amber deposits were discovered belongs to the lithological unit A, which was divided into two subunits (Moreau 1993; Néraudeau et al. 2002, 2005): A1, sand of various grain sizes, arranged in large cross beddings, bearing abundant lignite and amber accumulations; and A2, fine sand, mainly arranged in horizontal beds, bearing rare wood remains. In the Cadeuil 


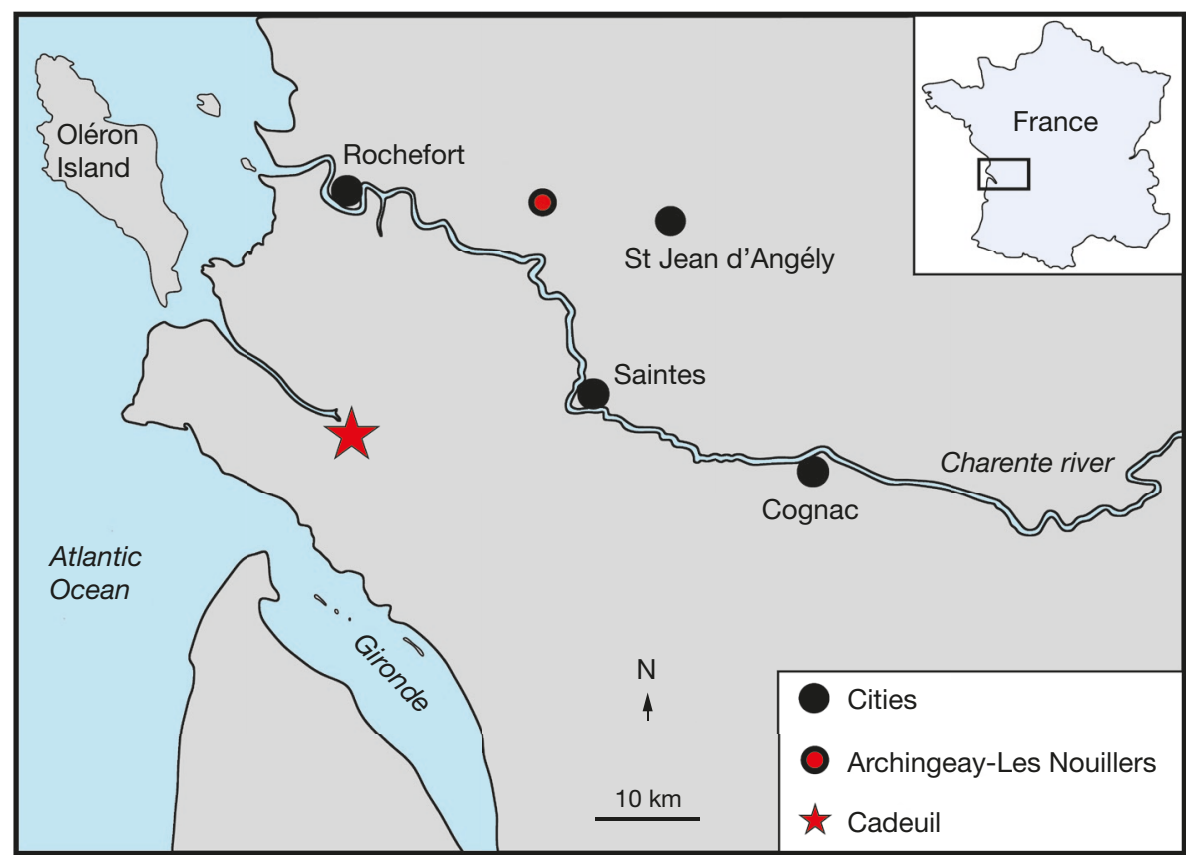

FIG. 1. - Map showing the location of the Cretaceous Charentese amber deposit in Cadeuil near Sainte-Gemme. The location of the largest deposit of Charentese amber, Archingeay-Les Nouillers, is also marked with a red dot.

area, the main amber deposit lies at the top of subunit $\mathrm{A} 1$ (Néraudeau et al. 2008). This geological section consists of $2 \mathrm{~m}$ of coarse sand, which is of brackish to coastal marine origin (Néraudeau et al. 2008). The sand includes three remarkable fossiliferous horizons, the amber is found in horizon A1b which is an accumulation of lignite (fossil wood) and horizon A1c which is a hard and coarse sandstone with metric cross beddings, corresponding to a succession of channels (Néraudeau et al. 2008). According to palynology, Cadeuil amber may be dated as late Albian in age (Néraudeau et al. 2002), but the horizons where the amber is found contain dynocysts, which range from the late Albian to the Cenomanian (Néraudeau et al. 2008). Similarly, the palynomorphs from the overlying subunit $\mathrm{A} 2$ are indicative of a latest Albian-early Cenomanian age, but ostracod and foraminifer assemblages from the upper part of subunit A1 (A1c) suggest an early Cenomanian age only (Peyrot et al. 2019). Thus, the amber from Cadeuil can be dated as latest Albian-earliest Cenomanian, although it was considered reliably dated as early Cenomanian in Perrichot et al. (2010). In comparison with other amber deposits from the region, Cadeuil represents a depositional environment which is more strongly influenced by marine conditions (Néraudeau et al. 2008). Furthermore, the abundance of algal inclusions suggests that the resin was produced during periods of algal blooms and was probably exuded from submerged conifer roots (Néraudeau et al. 2008). Cadeuil is the second largest amber deposit in the Charente-Maritime department, after Archingeay-Les Nouillers. However, only two beetle specimens were found among the about hundred fossil arthropods, mainly insects, from this deposit (VP, pers. data): the specimen studied herein and the sample CDL-2.23 (an isolated elytron).

\section{STUDIED MATERIAL, IMAGING AND MICROTOMOGRAPHY}

The specimen IGR.CDL-2.42 is included in an irregular, polished prism of amber (Fig. 2). The holotype is slightly distorted, possibly as a result of taphonomic processes after death or later on because of pressure exerted on the amber from the overlying sediment. The head and pronotum are fractured, the pronotum is almost completely separated from the elytra, and the apex of the abdomen is heavily distorted and partly missing. The elytra and wings of the specimen are separated from the body (Fig. 2). The specimen is preserved inside the amber fragment alone, but the fragment was originally part of a larger amber piece ('CDL-2' depicted in Perrichot 2005: fig. 10) containing 47 other arthropods and various microorganisms. This piece was cut into 50 subfragments for access to all inclusions and their detailed morphological features. Several of these insect syninclusions have been described elsewhere already (e.g., Perrichot et al. 2006, 2009; Flössner \& Fryer 2016). The amber piece containing the specimen is nearly transparent. Amber pieces like this are uncommon since most Cretaceous French ambers are usually translucent to opaque (Lak et al. 2008).

Photographs under reflected light were taken with a Zeiss Discovery V16 stereoscope. Photomicrographs with green background were taken under the eGFP mode (Zeiss Filter Set 10; excitation/emission: 450-490/515-565 nm). To uncover additional morphological details in the very small specimen, it was imaged using a propagation phase-contrast $\mathrm{X}$-ray synchrotron (PPC-SR $\mu \mathrm{CT}$ ). The scan was conducted at the European Synchrotron Radiation Facility (ESRF) in Grenoble, France. The specimen was imaged at the beamline ID19 using 1999 projections obtained through 360 degrees continuous rotation of the sample, with a multilayer mono- 
chromatic beam set at $20.5 \mathrm{keV}$, an isotropic voxel size of $1.36 \mu \mathrm{m}, 30 \mathrm{~mm}$ of propagation distance, and $0.5 \mathrm{~s}$ of exposure time (see technical details in Lak et al. 2008 and Soriano et al. 2010). After acquisition, ring artefact correction and 16 bits conversion, the volume was segmented using a filtered back projection algorithm in edge detection mode adapted for local tomography applications (PyHST software, ESRF). The tomographic data were subsequently analyzed using the VG StudioMax (3.0) software and a three-dimensional model was reconstructed from the segmented model.

The map showing the location of the Cadeuil deposit was created in CorelDRAW X8.

\section{SYSTEMATIC PALEONTOLOGY}

Order COLEOPTERA Linnaeus, 1758

Suborder POLYPHAGA Emery, 1886

Superfamily STAPHYLINOIDEA Latreille, 1802

Family JACOBSONIIDAE Heller, 1926

Genus Derolathrus Sharp in Sharp \& Scott, 1908

Derolathrus capdoliensis n. sp. (Figs 2-5)

urn:Isid:zoobank.org:act:956059B5-71DF-457C-B8D8-49C8BB3F4ED6

HolOTYPE. - IGR.CDL-2.42, slightly distorted specimen, sex indeterminate (Fig. 2). Deposited in the Geological Department and Museum of the University of Rennes, France.

Eтyмology. - Derived from 'Capdolium', the latin name of the type locality Cadeuil.

Type LOCALITY. - Charentese amber; lithological horizon A1b from Cadeuil quarry at Sainte-Gemme, Charente-Maritime department, France.

AGE. — Early-Late Cretaceous, latest Albian-earliest Cenomanian.

DiAGNOSIs. - Head subglabrous, without deep setiferous punctures. Antennae 11-segmented, apical two antennomeres not completely fused. Antennomere 10 slightly broader and shorter than the following segment, antennomere 11 pointed apically. Eyes large, with c. 30 ommatidia, their diameter slightly greater than the distance from their anterior margin to the antennal insertions. Pronotum rather parallel-sided, broadest in the anterior quarter. Pronotal disc with an oval medial depression with a raised longitudinal groove. Femora distinctly clavate.

\section{DESCRIPTION}

Body minute, subcylindrical, narrowly elongate. Length from clypeus to apex of the preserved part of abdomen $0.76 \mathrm{~mm}$, $0.22 \mathrm{~mm}$ wide across the broadest point of the elytra. Body subglabrous dorsally, dark brown to black (Figs 2; 3).

Head oval, $0.2 \mathrm{~mm}$ long from clypeus to distalmost part of the neck, abruptly constricted behind the eyes and with a distinct neck region, slightly fractured. Head surface glabrous, lacking carinae, raised ridges or deep punctures. Mandibles small, slender, curved. Maxillary palpomeres three-segmented, with apical palpomere aciculate and the penultimate palpomere distinctly larger, approximately three times the length of the following segment and broadest in the basal third. Eyes oval, somewhat protruding, multifaceted, and consisting of approximately 30 ommatidia. Antennae 11-segmented, concealed from above and inserted anterior to the eyes, separated by slightly less than the diameter of the eyes. Antennomere 1 (scape) globular, approximately as long as wide, antennomere 2 (pedicel) 0.9 times as long and 0.8 times as wide as the preceding segment, more elongate and barrel shaped; antennomeres 3-9 moniliform, gradually shortening and widening apically, antennomeres 10-11 forming a compact club; antennomere 100.9 times as long and 1.1 times as broad as the following segment, widest apically; 11 pointed apically (Figs 4; 5). Temples short, less than a quarter of the length of the eye.

Pronotum slightly distorted, $0.19 \mathrm{~mm}$ long, 1.1 times longer than wide, slightly wider than the head, approximately parallel-sided. Widest in anterior quarter. Anterior pronotal angles rounded, posterior pronotal angles obtuse. Pronotal disc with an oval medial depression with a raised longitudinal groove running from the basal quarter to the anterior quarter (Fig. 5A: pd, pg). Ventral side of pronotum strongly deformed. Procoxae globular, separated by approximately a third of their diameter across the broadest point. Mesocoxae rounded, further apart than procoxae, separated by more than half of their diameter. Metaventrite $0.24 \mathrm{~mm}$ long, broadening posteriorly and wider than head. Scutellum not visible.

Legs short, slender with the exception of the apically swollen femur. Trochanters distinctly large, trapezoidal. Femora broadened, clavate (Fig. 5B). Tibiae slender, twice as broad in apical half as at base, lacking apical spurs. Tarsus 3-segmented, third tarsomere longer than the basal two segments combined. Claws simple, empodium not apparent.

Elytra incomplete, narrower than pronotum basally, smoothly broadening towards the middle, and narrowing apically. Hind wings present, venation strongly reduced, ventral margin with approximately 30 elongate setae, dorsal margin with about 30 minute setae.

Abdomen poorly preserved, apical portion apparently missing. Intercoxal process of ventrite 1 broadly rounded.

\section{DISCUSSION}

SYSTEMATIC POSITION OF D. CAPDOLIENSIS N. SP.

The new fossil species can be placed into the family Jacobsoniidae on the basis of its minute size, narrowly elongate body, elongate prothorax, absence of a visible scutellum, concealed antennal insertions, and a distinctly elongate metaventrite (Philips et al. 2002; Lawrence \& Leschen 2010). It can be placed into the extant genus Derolathrus based on its exceptionally small body size (incomplete length of $0.76 \mathrm{~mm}$ ), 3-3-3 tarsal formula, 11-segmented antennae with a compact two-segmented apical club, and aciculate apical maxillary palpomeres (Sen Gupta 1979; Löbl \& Burckhardt 1988; Philips et al. 2002; Peck 2010; Lawrence \& Ślipiński 2013). In terms of its gross morphology, D. capdoliensis n. sp. shows close similarities with extant congenerics as well as with Derolathrus fossils known from Cretaceous Kachin amber (Yamamoto 

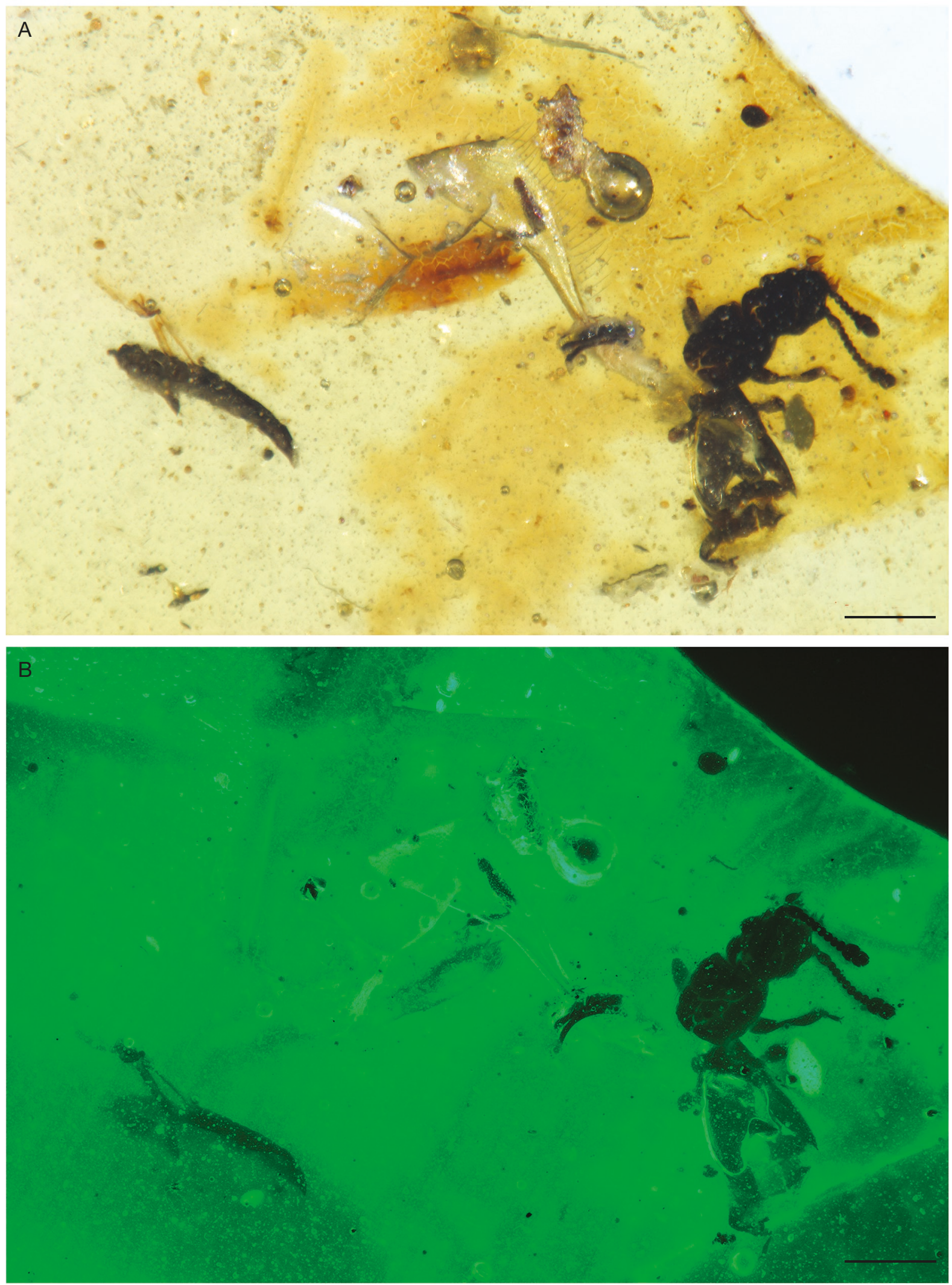


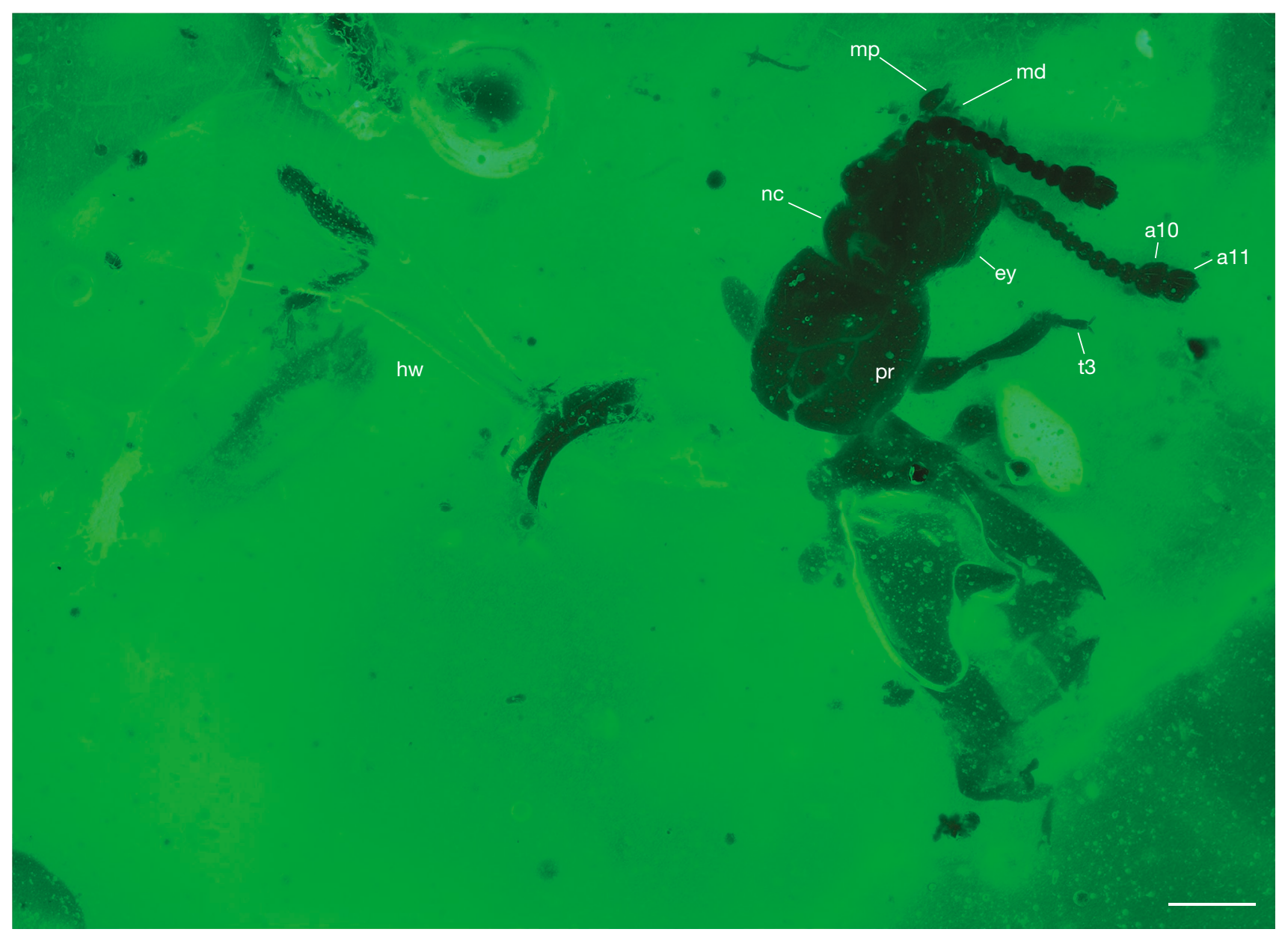

FIG. 3. - Morphological details of the holotype of Derolathrus capdoliensis n. sp. (IGR.CDL-2.42) in dorsal view under green fluorescence. Abbreviations: a10-11, antennomeres 10-11; ey, eye; hw, hindwing; md, mandible; mp, maxillary palpomeres; nc, neck region; pr, pronotum; t3, protarsomere 3. Scale bar: 100 $\mu$ m.

et al. 2017). It is probable that if the abdominal region of the beetle was complete, the elytra would expose the abdominal apex, similarly to the Cretaceous $D$. abyssus from Kachin amber (Yamamoto et al. 2017). Given that the elytra cover the abdomen completely in extant members of the genus, it is possible that this character represent a plesiomorphy.

D. capdoliensis n. sp. differs from the Cretaceous fossil species $D$. abyssus known from Kachin amber in having a more elongate metaventrite, clearly not shorter than the abdomen (Yamamoto et al. 2017), and from the Eocene D. groehni from Baltic amber in having more finely faceted ommatidia with more than 15 ocelli (Cai et al. 2016). Unlike D. anophthalmus Franz, 1969, apparently endemic to the Canary Islands, D. capdoliensis n. sp. has large eyes and is alate (Franz 1969). The presence of well-developed eyes also separates the new species from $D$. parvulus (Rücker 1983) and D. troglophilus (Sen Gupta 1979). It differs from D. atomus Sharp in Sharp \& Scott 1908, D. ceylonicus (Sen Gupta 1979), and an undescribed species from New Zealand in the presence of a pronotal depression (Sharp \& Scott 1908; Sen Gupta 1979; Lawrence $\&$ Leschen 2010). While it shares with D. cavernicolus Peck, 2010 and D. insularis (Dajoz 1973) the presence of a medial pronotal depression, it differs from the former in the head lacking densely scattered, large, setiferous punctures and pronotum without a longitudinal subtriangular depression, and from the latter in pronotum more parallel-sided and not expanding anteriorly. The new species differs from $D$. sharpi Grouvelle in Grouvelle \& Raffray 1912 in having larger eyes, whose diameter is slightly greater than distance to the base of antennae (Grouvelle \& Raffray 1912). Derolathrus capdoliensis $\mathrm{n}$. sp. differs from all hitherto described species in the antennal club consisting of two antennomeres that are very closely spaced but nonetheless discrete and not entirely fused.

The new species can be considered as basal within Derolathrus based on its antennal structure. While all other congenerics have the apical two antennomeres clearly fused, sometimes appearing as one uniform segment (e.g. D. insularis), in D. capdoliensis n. sp. the two apical segments are very close but not fused, as indicated by the microtomographs in Figures 4 and 5 showing a slight separation between the two segments. It is thus possible that the distinctly 11-segmented condition is ancestral and that the apical club became progressively more fused in later-diverging species of the genus. However, evaluating whether any given set of characters represent true plesiomorphies depends on resolving the internal phylogeny of Jacobsoniidae and its systematic position within Polyphaga. 


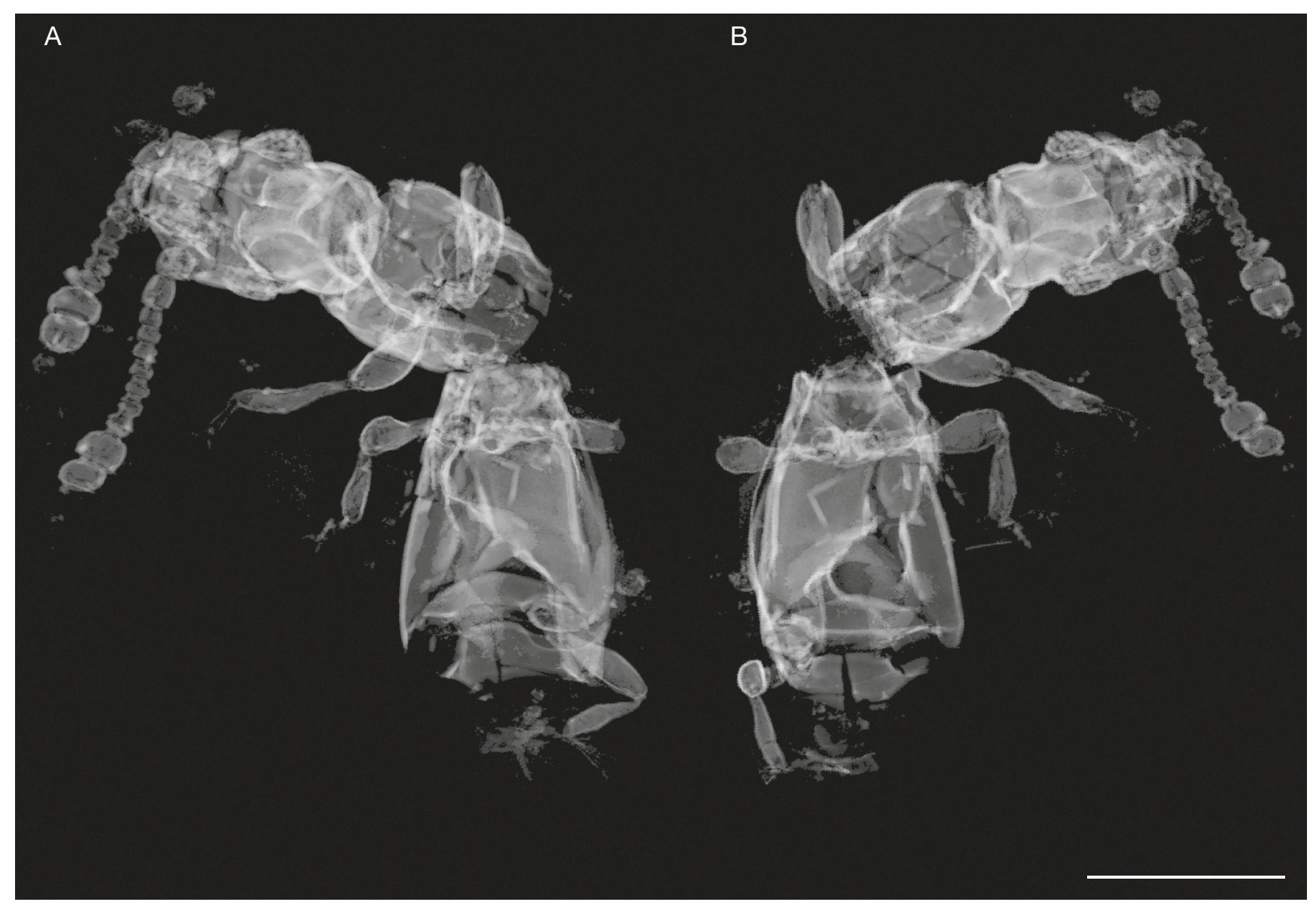

FIG. 4. - PPC-SR 4 CT reconstruction of the holotype of Derolathrus capdoliensis n. sp. (IGR.CDL-2.42): A, ventral view; B, dorsal view. Scale bar: 200 um.

HUNDRED MILLION YEARS OF

MORPHOLOGICAL STASIS IN JACOBSONIIDAE

Derolathrus capdoliensis n. sp. possibly predates the two Cretaceous Jacobson's beetles described to date, D. abyssus and Sarothrias cretaceus from Kachin amber mined in northern Myanmar (Cai et al. 2017; Yamamoto et al. 2017). Volcanoclastic matrix from the Kachin amber-bearing horizon was dated radiometrically at $98.79 \pm 0.62 \mathrm{Ma}$ (Shi et al. 2012), corresponding to the early Cenomanian. Mao et al. (2018) pointed out that given the design of the analysis, this radiometric date should be interpreted as the minimum age of the deposit. Even when adhering to this conservative minimum age of Kachin amber, the age of Charentese amber remains uncertain and is either latest Albian or earliest Cenomanian (Néraudeau et al. 2002; Perrichot et al. 2010). While it is thereby unclear if D. capdoliensis n. sp. predates other Jacobson's beetles from Kachin amber, it nonetheless considerably expands the known range of the family during the mid-Cretaceous.

The new species closely resembles its modern and fossil congenerics. It shares the most similarities with the Cretaceous $D$. abyssus and the extant $D$. ceylonicus known from Sri Lanka. D. capdoliensis n. sp. thus provides a testimony to a prolonged morphological stasis within Jacobsoniidae since at least the earliest Cenomanian, some $100 \mathrm{Ma}$ ago. A highly conserved morphology within the family is also apparent from the described Cretaceous fossil species (Cai et al. 2017; Yamamoto et al. 2017) and probably indicates that the ecology of the group has changed little since this time. Similar degrees of morphological stasis have been reported in other Cretaceous beetles inhabiting leaf litter and decaying vegetational matter (e.g. Clarke \& Chatzimanolis 2009; Peris et al. 2014; Yamamoto \& Solodovnikov 2016; Ross 2019, 2020; Liu et al. 2020; Yin \& Zhou 2020). It is possible that the relative stability of this microhabitat through deep time protected these taxa from strong selective pressures and extinction (Peris \& Háva 2016), providing 'refuge niches' (McKenna et al. 2015a; Lü et al. 2019). Indeed, some of the most diverse groups of beetles such as many ground beetles (Carabidae) and rove beetles (Staphylinidae) occupy predominantly leaf litter, soil, and rotting plant matter, and so the role of refuge niches in acting as a museum of biodiversity may be a more general evolutionary phenomenon across Coleoptera.

HistoricAl BiogeOgRAPHY OF JACOBSON'S BEETLES

Derolathrus capdoliensis n. sp. represents the $11^{\text {th }}$ described species of the genus Derolathrus. Members of the genus are rarely collected, which may be in part due to their minute size (most species do not exceed $1 \mathrm{~mm}$ in length) and cryptic habits. Derolathrus adults and larvae have been collected in fungus-rich and humid microhabitats such as leaf litter, under bark, in rotten 


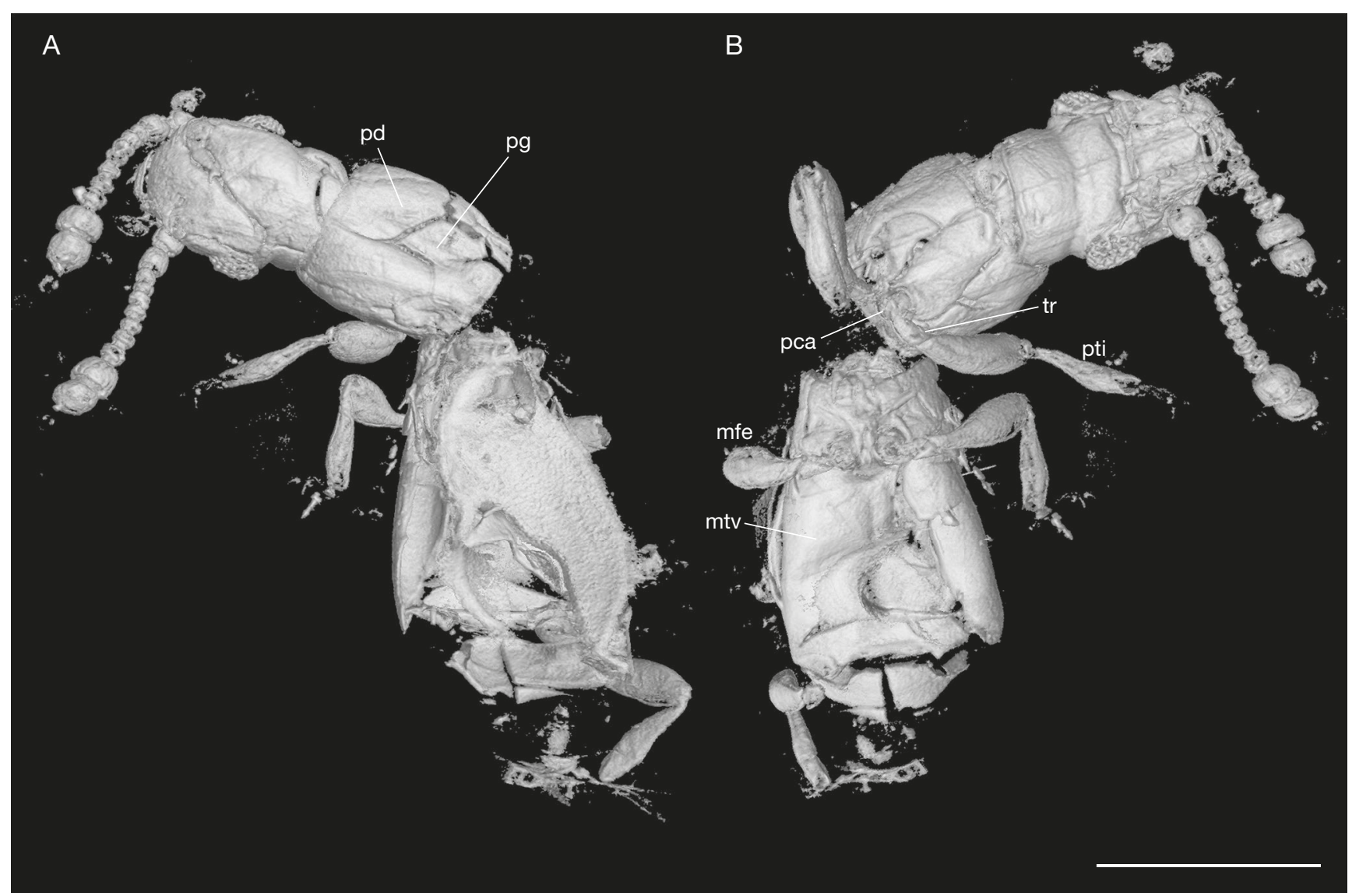

FIG. 5. - Enlargement of the PPC-SR $\mathrm{CCT}$ reconstruction details of the holotype of Derolathrus capdoliensis n. sp. (IGR.CDL-2.42): A, dorsal view; B, ventral view. Abbreviations: mfe, mesofemur; mtv, metaventrite; pg, pronotal groove; pca, procoxa; pd, pronotal depression; pti, protibia; tr, trochanter. Scale bar: 200 4 m.

palm wood, bat guano, and fungal fruiting bodies (Lawrence $\&$ Leschen 2010). Derolathrus occurs in tropical and subtropical regions throughout the world as well as on isolated landmasses and archipelagos such as the Hawaii Islands, Galapagos Islands, the Solomon Islands, Australia, and New Zealand (Philips et al. 2002, Peck 2010). This distributional pattern could have arisen as a result of widespread dispersal. Given their minute size and wing morphology, Jacobson's beetles could be carried by wind currents over long distances (Cai et al. 2016). Our discovery in Charentese amber reveals that Jacobsoniidae had a potentially cosmopolitan distribution during the mid-Cretaceous, encompassing the Tethyan and Austral realms. Jacobsoniidae occurred in present-day Europe until at least the Eocene, as evidenced by specimens from Baltic amber (Cai et al. 2016). Baltic amber probably formed from resin secreted during the Middle Eocene climatic optimum when northern Europe had a warm and equitable climate, as evidenced by the occurrence of insects such as mantises and stick insects in the deposit (Archibald \& Farrell 2003; Brunke et al. 2019). It is possible that Jacobsoniidae became extinct in Europe following the cooling after the Eocene climatic optimum that gave the continent the temperate climate with colder winter temperatures that we largely know today (Hren et al. 2013).

\section{Acknowledgements}

This study is dedicated to the late Eugène Arnaud (19222009) who generously donated a large part of his amber collection from Cadeuil to the University of Rennes, including the piece containing the specimen described herein. Financial support for field studies and collection of Charentese amber was provided by French National Research Agency grant BLAN07-1-184190 (project AMBRACE to D. Néraudeau, University of Rennes); and support for the present study was provided by the Strategic Priority Research Program of the Chinese Academy of Sciences (XDB26000000 and XDB18000000), the National Natural Science Foundation of China (41672011 and 41688103), and the Second Tibetan Plateau Scientific Expedition and Research (2019QZKK0706). The work of David Peris was supported by the Alexander von Humboldt Foundation, Germany and the Ministry of Science, Innovations and Universities, Spain (project "CRE", Spanish AEI/FEDER, UE CGL2017-84419). We are grateful to Paul Tafforeau and Carmen Soriano (ESRF) for the synchrotron imaging of the specimen and Ms. Su-Ping Wu for technical help with $3 \mathrm{D}$ reconstructions. We thank anonymous reviewers for their valuable comments. 


\section{REFERENCES}

ArChibald S. B. \& Farrell B. D. 2003. - Wheeler's dilemma. Acta Zoologica Cracoviensia 46: 17-23.

BI W.-X., CHEN C.-C. \& LiN M.-Y. 2015. - First record of Jacobsoniidae (Coleoptera) from China with description of a new species of Sarothrias Grouvelle. ZooKeys 496: 53-60. https://doi. org/10.3897/zookeys.496.8620

Bouchard P., Bousquet Y., Davies A. E., Alonso-Zarazaga M. A., Lawrence J. F., Lyal C. H., Newton A. F., Reid C. A. M., SchmitT M., ŚLIPIŃSKi S. A. \& SMITH A. B. T. 2011. Family-group names in Coleoptera (Insecta). ZooKeys 88: 1-972. https://doi.org/10.3897/zookeys.88.807

Brunke A. J., ZyŁa D., Yamamoto S. \& Solodovnikov A. 2019. - Baltic amber Staphylinini (Coleoptera: Staphylinidae: Staphylininae): a rove beetle fauna on the eve of our modern climate. Zoological Journal of the Linnean Society 187: 166-197. https://doi.org/10.1093/zoolinnean/zlz021

Cai C., Leschen R. A., Liu Y. \& Huang, D. 2016. - First fossil jacobsoniid beetle (Coleoptera): Derolathrus groehni n. sp. from Eocene Baltic amber. Journal of Paleontology 89: 762-767. https:// doi.org/10.1017/jpa.2015.65

CAi C., ŚLipińsKi A., Leschen R. A. B., Yin Z., Zhuo D. \& HuANG D. 2017. - The first Mesozoic Jacobson's beetle (Coleoptera: Jacobsoniidae) in Cretaceous Burmese amber and biogeographical stasis. Journal of Systematic Palaeontology 16: 543-550. https:// doi.org/10.1080/14772019.2017.1314388

Cai C., LAWRENCE J. F., Yamamoto S., LeSChEN R. A. B., NewTON A. F., ŚlipińsKi A., Yin Z., HuAng D. \& ENGEL M. S. 2019. Basal polyphagan beetles in mid-Cretaceous amber from Myanmar: biogeographic implications and long-term morphological stasis. Proceedings of the Royal Society B: Biological Sciences 286: https://doi.org/10.1098/rspb.2018.2175

Cai C., Tihelka E., Giacomelli M., LaWrence J. F., Ślipiński A., Kundrata R., Yamamoto S., Thayer M. K., Newton A. F., Leschen R. A. B., Gimmel M. L., LÜ L., Engel M. S., HuAng D., Pisani D. \& Donoghue P. C. J. 2021. — Integrated phylogenomics and fossil data illuminate the evolution of beetles. BioRxiv. https://doi.org/10.1101/2021.09.22.461358

Chatzimanolis S., Newton A., Soriano C. \& Engel M. S. 2013. - Remarkable stasis in a phloeocharine rove beetle from the Late Cretaceous of New Jersey (Coleoptera, Staphylinidae). Journal of Paleontology 87: 177-182. https://doi.org/10.1666/12114.1

Clarke D. J. \& Chatzimanolis S. 2009. - Antiquity and longterm morphological stasis in a group of rove beetles (Coleoptera: Staphylinidae): description of the oldest Octavius species from Cretaceous Burmese amber and a review of the 'Euaesthetine subgroup' fossil record. Cretaceous Research 30: 1426-1434. https://doi.org/10.1016/j.cretres.2009.09.002

Crowson R. A. 1959. - Studies on the Dermestoidea (Coleoptera), with special reference to the New Zealand fauna. Transactions of the Royal Entomological Society of London 111: 81-94. https:// doi.org/10.1111/j.1365-2311.1959.tb02277.x

Crowson R. A. 1960. - The phylogeny of Coleoptera. Annual Review of Entomology 5: 111-134. https://doi.org/10.1146/ annurev.en.05.010160.000551

DAJOZ R. 1973. - Coléoptères Lathridiidae de Madagascar et des Mascareignes. Bulletin du Muséum National d'Histoire Naturelle 64: 1049-1056.

FlösSNER D. \& FrYer G. 2016. An Early Cretaceous anomopod (Crustacea: Branchiopoda) preserved in amber that reveals an unexpected venture during the evolution of the order. Journal of Natural History 50: 1291-1304. https://doi.org/10.1080/00 222933.2015.1134693

Franz H. 1969. - Eine neue gattung und art aus der familie Colydiidae von den Kanarischen Inseln (Coleoptera). Eos, Madrid 44: 135-139.
Grouvelle A. \& Raffray A. 1912. - Supplément à la liste des Coléoptères de la Guadeloupe. Annales de la Société Entomologique France 81: 289-312.

HÂvA J. 2016. — Updated world catalogue of the family Jacobsoniidae (Coleoptera: Derodontoidea). Studies and Reports, Taxonomic Series 12: 345-352.

HÁvA J. \& LÖBL I. 2005. - A world catalogue of the family Jacobsoniidae (Coleoptera). Studies and reports of District Museum Prague-East, Taxonomical Series 1: 89-94.

HeLleR K. M. 1926. — Fauna sumatrensis (Beitrag Nr. 29). Rhysodidae et familia nova Jacobsoniidae (prope Rhysodidae? Col.). Supplementa Entomologica 14: 126-128.

Hren M. T., Sheldon N. D., Grimes S. T., Collinson M. E., Hooker J. J., Bugler M. \& Lohmann K. C. 2013. - Terrestrial cooling in Northern Europe during the Eocene-Oligocene transition. Proceedings of the National Academy of Sciences 110: 7562-7567. https://doi.org/10.1073/pnas.1210930110

lak M., Néraudeau D., Nel A., Cloetens P., Perrichot V. \& TAFFOREAU P. 2008. - Phase contrast X-ray synchrotron imaging: opening access to fossil inclusions in opaque amber. Microscopy and Microanalysis 14: 251-259. https://doi.org/10.1017/ S1431927608080264

LAWRENCE J. F. 2016. - Classification (families and subfamilies), in Beutel R. G. \& Leschen R. A. B. (eds.), Handbook of Zoology. Arthropoda: Insecta. Coleoptera, Beetles. Morphology and Systematics. Vol. 1: Archostemata, Adephaga, Myxophaga, Polyphaga partim. Walter de Gruyter, Berlin, New York: 13-22.

LAWRENCE J. F. \& LESCHEN R. A. B. 2010. - Jacobsoniidae Heller, 1926, in Leschen R. A. B., Beutel R. G. \& Lawrence J. F. (eds.), Handbook ofZoology. Arthropoda: Insecta. Coleoptera, Beetles. Morphology and systematics. Vol. 2: Elateroidea, Bostrichiformia, Cucujiformia partim. Walter de Gruyter, Berlin, New York: 190-195.

LAWRENCE J. F. \& NEWTON A. F. 1995. — Families and subfamilies of Coleoptera (with selected genera, notes, references and data on family-group names), in Pakaluk J. \& Ślipiński S. A. (eds.), Biology, Phylogeny, and Classification of Coleoptera. Papers Celebrating the 80th Birthday of Roy A. Crowson. Muzeum i Instytut Zoologii Polska Akademia Nauk, Warsaw: 779-1006.

LAWRENCE J. F. \& ŚLIPIŃSKI A. 2013. - Australian Beetles. Morphology, Classification and Keys. CSIRO Publishing, Collingwood, $576 \mathrm{p}$.

LaWrence J. F., ŚlipińSKi A., SeAgo A. E., Thayer M. K., Newton A. F. \& Marvaldi A. E. 2011. - Phylogeny of the Coleoptera based on morphological characters of adults and larvae. Annales Zoologici 61: 1-217. https://doi.org/10.3161/000345411X576725

LiU Y., Tinelka E., Yamamoto S., Yin Z., Huang D., Tian L. \& CAI C. 2020. - The first fossil record of the rove beetle subfamily Protopselaphinae (Coleoptera: Staphylinidae) from midCretaceous Burmese amber. Cretaceous Research 110: 104416. https://doi.org/10.1016/j.cretres.2020.104416

LÖBL I. \& BuRCKHARDT D. 1988. - Revision der gattung Sarothrias mit bemerkungen zur familie Jacobsoniidae (Coleoptera). Stuttgarter Beiträge zur Naturkunde, Serie A (Biologie) 422: 1-23.

LÜ L., Cai C.-Y., Zhang X., Newton A. F., ThaYer M. K. \& ZHOU H.-Z. 2019. — Linking evolutionary mode to palaeoclimate change reveals rapid radiations of staphylinoid beetles in low-energy conditions. Current Zoology: zoz053. https://doi. org/10.1093/cz/zoz053

MaO Y. Y., Liang K., Su Y., Li J. G., RaO X., Zhang H., Xia F., FU Y., CAI C. \& HuANG D. 2018. - Various amberground marine animals on Burmese amber with discussions on its age. Palaeoentomology 1: 91-103. https://doi.org/10.11646/palaeoentomology.1.1.11

McKenna D. D., Farrell B. D., Caterino M. S., Farnum C. W., Hawks D. C., Maddison D. R., Seago A. E., Short A. E. Z., NeWTON A. F. \& ThaYer M. K. 2015a. - Phylogeny and evolution of Staphyliniformia and Scarabaeiformia: forest litter as a stepping stone for diversification of nonphytophagous beetles. Systematic Entomology 40: 35-60. https://doi.org/10.1111/syen.12093 
McKenna D. D., Wild A. L., Kanda K., Bellamy C. L., Beutel R. G., Caterino M. S., Farnum C. W., Hawks D. C., Ivie M. A., Jameson M. L., Leschen R. A. B., Marvaldi A. E., Mchugh J. V., Newton A. F., Robertson J. A., Thayer M. K., Whiting M. F., Lawrence J. F., Ślipiński A., Maddison D. R. \& FARRELL B. D. 2015b. - The beetle tree of life reveals that Coleoptera survived end-Permian mass extinction to diversify during the Cretaceous terrestrial revolution. Systematic Entomology 40: 835-880. https://doi.org/10.1111/syen.12132

McKenna D. D., Shin S., Ahrens D., Balke M., Beza-Beza C., Clarke D. J., Donath A., Escalona H. E., Friedrich F., Letsch H., Liu S., Maddison D., Mayer C., Misof B., Murin P. J., Niehuis O., Peters R. S., Podsiadlowski L., Pohl H., Scully E. D., Yan E. V., Zhou X., Ślipiński A. \& Beutel R. G. 2019. - The evolution and genomic basis of beetle diversity. Proceedings of the National Academy of Sciences. https://doi. org/10.1073/pnas.1909655116

MOREAU P. 1993. - La transgression cénomanienne sur la marge septentrionale du bassin de l'Aquitaine (Charentes), flanc Nord du synclinal de Saintes et Angoumois. Modalités d'une invasion marine, aspects stratigraphiques, sédimentologiques et paléogéographiques. I. Analyse stratigraphique et identification des milieux. Unpublished thesis, Universite de Poitiers, $505 \mathrm{p}$.

Néraudeau D., Perrichot V., Dejax J., Masure E., Nel A., Philippe M., Moreau P., Guillocheau F. \& Guyot T. 2002. - Un nouveau gisement à ambre insectifere et à végétaux (Albien terminal probable): Archingeay (Charente-Maritime, France). Geobios 35: 233-240. https://doi.org/10.1016/S0016-6995(02)00024-4

Néraudeau D., Perrichot V., Colin J.-P., Girard V., Gomez B., Guillocheau F., Masure E., Peyrot D., Tostain F., VIDET B. \& VulLo R. 2008. - A new amber deposit from the Cretaceous (Uppermost Albian- Lowermost Cenomanian) of southwestem France. Cretaceous Research 29: 925-929. https:// doi.org/10.1016/j.cretres.2008.05.009

Néraudeau D., Vullo R., Gomez B., Perrichot V. \& Videt B. 2005. - Stratigraphie et paléontologie (plantes, vertébrés) de la série paralique Albien terminal-Cénomanien basal de TonnayCharente (Charente-Maritime, France). Comptes Rendus Palevol 4: 79-93. https://doi.org/10.1016/j.crpv.2004.11.008

PeCK S. B. 2010. - Derolathrus cavernicolus n. sp., a beetle family new for North America (Coleoptera: Jacobsoniidae). Annals of the Entomological Society of America 103: 1-6. https://doi. org/10.1093/aesa/103.1.1

Peris D., Delclòs X., Soriano C. \& Perrichot V. 2014. — The earliest occurrence and remarkable stasis of the family Bostrichidae (Coleoptera: Polyphaga) in Cretaceous Charentes amber. Palaeontologia Electronica 17: 1-8. https://doi.org/10.26879/408

Peris D. \& HÁVA J. 2016. - New species from Late Cretaceous New Jersey amber and stasis in subfamily Attageninae (Insecta: Coleoptera: Dermestidae). Journal of Paleontology 90: 491-498. https://doi.org/10.1017/jpa.2016.51

PERRICHOT V. 2005. - Environnements paraliques à ambre et à végétaux du Crétacé nord-aquitain (Charentes, Sud-Ouest de la France). Mémoires de Géosciences Rennes 118: 310 p.

Perrichot V., Nel A., Guilbert E. \& Néraudeau D. 2006. Fossil Tingoidea (Heteroptera: Cimicomorpha) from French Cretaceous amber, including Tingidae and a new family, Ebboidea. Zootaxa 1203: 57-68. https://doi.org/10.11646/zootaxa.1203.1.3

Perrichot V., Nel A. \& Quicke D. L. J. 2009. — New braconid wasps from French Cretaceous amber (Hymenoptera, Braconidae): Synonymization with Eoichneumonidae and implications for the phylogeny of Ichneumonoidea. Zoologica Scripta 38: 79-88. https://doi.org/10.1111/j.1463-6409.2008.00358.x
Perrichot V., Néraudeau D. \& TAFForeau P. 2010. — Charentese amber, in Penney D. (ed.), Biodiversity of fossils in amber from the major world deposits. Siri Scientific Press, Manchester: 192-207.

Peyrot D., Barrón E., Polette F., Batten D. J. \& Néraudeau D. 2019. - Early Cenomanian palynofloras and inferred resiniferous forests and vegetation types in Charentes (southwestern France). Cretaceous Research 94: 168-189. https://doi.org/10.1016/j. cretres. 2018

Philips T. K., Ivie M. A. \& Giersch J. J. 2002. — Jacobsoniidae Heller 1926, in Arnett R. H. Jr., Thomas M. C., Skelley P. E. \& Frank J. H. (eds.), American Beetles. Vol. 2: Polyphaga: Scarabaeoidea through Curculionoidea. CRC Press, Boca Raton: 219-220.

Ross A. J. 2019. - Burmese (Myanmar) amber checklist and bibliography, 2018. Palaeoentomology 2: 22-84. https://doi. org/10.11646/palaeoentomology.2.1.5

Ross A. J. 2020. - Supplement to the Burmese (Myanmar) amber checklist and bibliography, 2019. Palaeoentomology 3: 103-118. https://doi.org/10.11646/palaeoentomology.3.1.14

RÜCKER H. W. 1983. - Hexasternum und Lathrapion, zwei neue gattungen und weitere neue arten der familie Merophysiidae (Coleoptera). Revue Suisse de Zoologie 90: 679-687. https://doi. org/10.5962/bhl.part.82006

SEN GUPTA T. 1979. - A new subfamily of Merophysiidae (Clavicornia: Coleoptera) and descriptions of two new species of Gomya Dajoz and its larva. Revue Suisse de Zoologie 86: 691-698. https:// doi.org/10.5962/bhl.part.82333

Sharp D. \& SCOTT H. 1908. - Coleoptera III (various). Fauna Hawaiiensis. University Press, Cambridge: 367-579.

Shi G., Grimaldi D. A., Harlow G. E., Wang J., Wang J., YanG M., LEI W., Li Q. \& Li X. 2012. — Age constraint on Burmese amber based on U-Pb dating of zircons. Cretaceous Research 37: 155-163. https://doi.org/10.1016/j.cretres.2012.03.014

Simpson G. G. 1944. - Tempo and Mode in Evolution. Columbia University Press, New York, 238 p.

Soriano C., Archer M., Azar D., Creaser P., Delclòs X., Godthelp H., Hand S., Jones A., Nel A., Néraudeau D., Ortega-Blanco J., Pérez-de la Fuente R., Perrichot V., Saupe E., Solózano-Kraemer M. \& TAFForeau P. 2010. Synchrotron X-Ray imaging of inclusions in amber. Comptes Rendus Palevol 9: 361-368. https://doi.org/10.1016/j.crpv.20

Toussaint E. F. A., Seidel M., Arriaga-Varela E., Hájek J., Král D., SeKerka L., Short A. E. Z. \& FiKÁčEK M. 2017. - The peril of dating beetles. Systematic Entomology 42: 1-10. https:// doi.org/10.1111/syen.12198

YAMAмOTO S. \& SolodovNiKOV A. 2016. — The first fossil Megalopsidiinae (Coleoptera: Staphylinidae) from Upper Cretaceous Burmese amber and its potential for understanding basal relationships of rove beetles. Cretaceous Research 59: 140-146. https:// doi.org/10.1016/j.cretres.2015

YAmamoto S., TAKAhashi Y. \& PARKer J. 2017. — Evolutionary stasis in enigmatic jacobsoniid beetles. Gondwana Research 45: 275-281. https://doi.org/10.1016/j.gr.2016.12.008

YIN Z. W. \& BI W.X. 2018. — New and little known Jacobsoniidae (Coleoptera) from China. Acta Entomologica Musei Nationalis Pragae 58: 11-16. https://doi.org/10.2478/aemnp-2018-0002

YIN Z. \& ZHOU D. 2020. - Scydmaenus linqibini sp. nov., a new fossil Scydmaenini in mid-Cretaceous amber from northern Myanmar (Coleoptera: Staphylinidae: Scydmaeninae). Palaeoentomology 3 (1): 36-40. https://doi.org/10.11646/palaeoentomology.3.1.4

ZHANG S.-Q., CHE L.-H., Li Y., LIANG D., PANG H., ŚLIPIŃSKI A. \& ZHANG P. 2018. - Evolutionary history of Coleoptera revealed by extensive sampling of genes and species. Nature Communications 9: art. 205. https://doi.org/10.1038/s41467-017-02644-4 